\title{
GLACIATIONS OF THE PINDAR RIVER VALLEY, SOUTHERN HIMALAYAS
}

\author{
By N. Ahmad and H. B. Saxena \\ (Department of Geology, Muslim University, Aligarh, India)
}

\begin{abstract}
The Pindari Glacier is situated in the heart of the Kumaon Hills in lat. $30^{\circ} 17^{\prime} \mathrm{N}$. and long. $80^{\circ} \mathrm{o}^{\prime} \mathrm{E}$. This glacier was visited by the authors in October 1959 when morphological and other observations were made. On the basis of these observations, it appears that during the last hundred years the rate of retreat of this glacier has been phenomenal, and it may be as much as $132 \mathrm{ft}$. $(40 \cdot 2 \mathrm{~m}$. $) / \mathrm{yr}$. There is also evidence that in the past the Pindari valley suffered at least two glacial advances.

Résumé. Le "Pindari Glacier" est situé au cœur des “Kumaon Hills” à la latitude de $30^{\circ} \mathrm{I} 7$ ' N et à la longitude de $80^{\circ} \mathrm{o}^{\prime} \mathrm{E}$. Ce glacier a été visité par les auteurs en Octobre r 959 qui y ont réalisé des observations morphologiques etc. Sur la base de ces observations, il apparaît que durant la dernière centaine d'années la vitesse de retrait de ce glacier a été phénomènale, puisqu'elle a pu atteindre jusqu'à $40,2 \mathrm{~m} / \mathrm{an}$. Il est d'autre part évident que dans le passé la "Pindari valley" a subi au moins deux avances glaciaires.

Zusammenfassung. Der Pindari Gletscher liegt im Herzen der Kumaon Berge in $30^{\circ} 17^{\prime} \mathrm{N}$ geogr. Breite und $80^{\circ} \mathrm{o}^{\prime} \mathrm{O}$ geogr. Länge. Dieser Gletscher wurde von den Verfassern im Oktober 1959 besucht, dabei wurden morphologische und andere wissenschaftliche Beobachtungen angestellt. Auf Grund dieser Beobachtungen offenbart sich ein phänomenaler Rückzug, der in den letzten hundert Jahren $40,2 \mathrm{~m} / \mathrm{Jahr}$ beträgt. Es ist ausserdem klar, dass das Pindari-Tal in der Vergangenheit mindestens zwei glazialen Vorstössen unterworfen war.
\end{abstract}

The Pindari Glacier, which lies in lat. $30^{\circ} \mathrm{I} 7^{\prime}$ N. and long. $80^{\circ} \mathrm{o}^{\prime}$ E. 75 miles ( $12 \mathrm{I} \mathrm{km}$.) north of Almora, is one of the most easily accessible glaciers in the Kumaon region. It is situated almost midway between the well-known peaks of Nanda Devi and Nanda Kot (Fig. I) in the Himalayas. Kapkot, to the south, is reached from Almora by bus or car, and from there the last 30 miles $(48 \mathrm{~km}$.) to the glacier have to be covered either on foot or by pony.

Owing to its ease of access the Pindari Glacier area has been a tourist resort since the beginning of the last century. It is therefore fortunate that a number of visitors have recorded their observations in the log books at the Phurkia Dak bungalow. The first published account of this glacier seems to be that of General R. Strachey (I847). In July I 906 the glacier was visited by Cotter and Brown (I906) who recorded the position of its snout. A Swiss expedition led by A. Heim visited this area in 1939, but it was mainly concerned with petrological studies. The present observations were made when the authors visited the Pindari Glacier in Octoher 1959 .

\section{The Pindari Glacier}

The Pindari Glacier (Fig. 2) is about 4 miles $(6 \cdot 4 \mathrm{~km}$.) long and it terminates just above the medial moraine of the Pindari and Banghatia Glaciers. This glacier is fed by the névé fields on the north-western side of Nanda Kot, the cirque on the eastern slopes of Nanda Khat and the Banghatia and Baria Glaciers.

The ice flowing from Nanda Kot and Nanda Khat merges at Traill's Pass, the saddle between the two peaks. As this ice moves southwards it becomes the Pindari Glacier. Since the Baria and Banghatia Glaciers are the main sources of the ice forming the Pindari Glacier, a detailed study of them was considered worthwhile.

The Baria Glacier is nourished by the névé fields along the western walls of the Pindari valley. It flows northwards and then turns east joining the Pindari Glacier south of Traill's Pass. The Banghatia Glacier is fed by the Tail-chhanguch and Shel-chhanguch Glaciers, the former receiving its ice from the cirque on the western side of Nanda Kot, while the latter is fed by the névé fields situated along the eastern wall of the Pindari Glacier, between Lamchhir Point (lat. $30^{\circ} \mathrm{I} 4^{\prime}$ N., long. $80^{\circ} 2^{\prime}$ E.) and Nanda Bhanar (lat. $30^{\circ}$ I $7^{\prime}$ N., long. $80^{\circ} 3^{\prime}$ E.). 
Furthermore, the Banghatia Glacier joins the Pindari Glacier from the east at a height of $12,500 \mathrm{ft}$. (3,810 m.). A number of hanging glaciers descend from the east to the Pindari valley but all of their snouts lie above $\mathrm{i} 6,000 \mathrm{ft}$. $(4,877 \mathrm{~m}$.).

From Traill's Pass the Pindari Glacier descends in two stages, each of about 2 miles $(3.2 \mathrm{~km}$.). In the first stage it descends $\mathrm{I}, 000 \mathrm{ft}$. $(305 \mathrm{~m}$.) but in the second it falls more than $3,500 \mathrm{ft}$. ( $1,067 \mathrm{~m}$.).

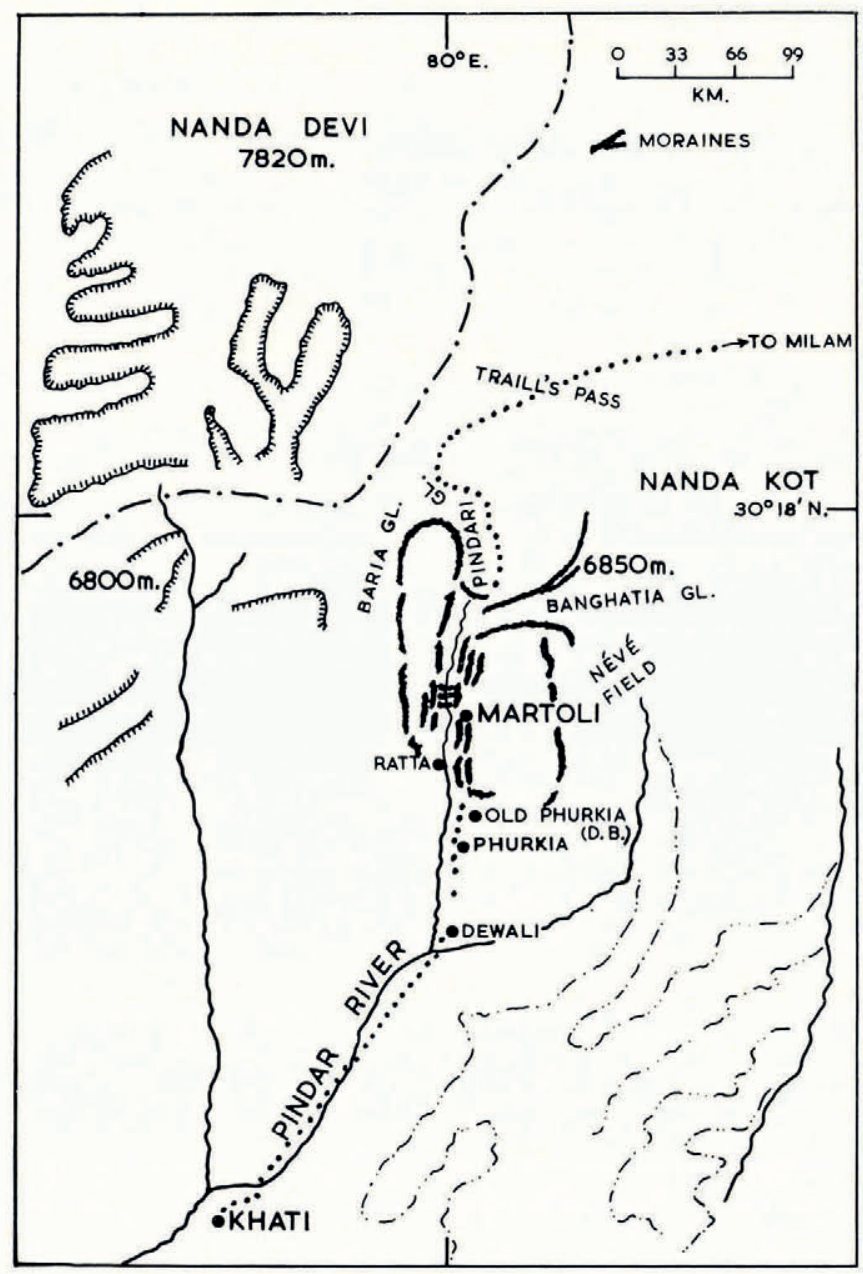

Fig. I. Map of the Pindar River valley, reconstructed from information by Heim and Gansser (I939)

The upper half of the glacier has an almost unbroken surface but the lower half is traversed by transverse and longitudinal crevasses. All the melt water from the glacier is collected by a subglacial stream which emerges from an ice cave at the snout and this is called the Pindar River.

\section{The Pindari Valley}

The glaciated section of the Pindari valley has an elliptical bowl shape, being 3 to 4 miles $(4.8$ to $6.4 \mathrm{~km}$.) in length with a maximum width of about 2 miles $(3 \cdot 2 \mathrm{~km}$.). The Pindar 
River emerges from this part of the valley through a narrow gorge and then flows in a roughly V-shaped valley (Figs. 3 and 4 ).

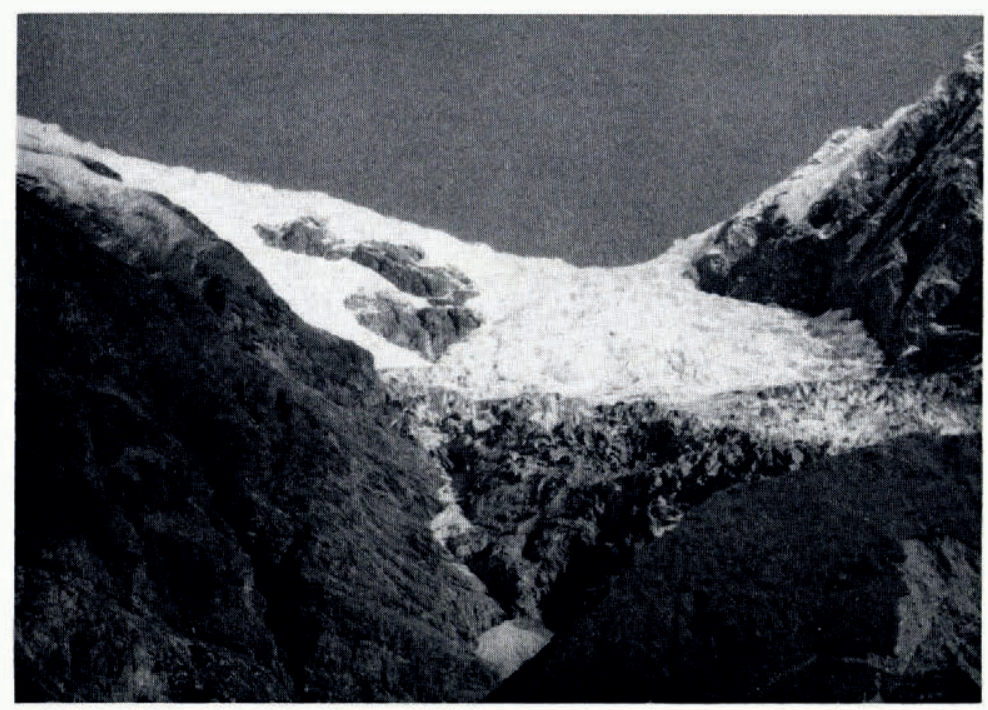

Fig. 2. The Pindari Glacier, showing its snout, the ice cave and the source of the Pindar River. Part of the medial moraine between the Banghatia and Pindari Glaciers is in the right foreground of the photograph

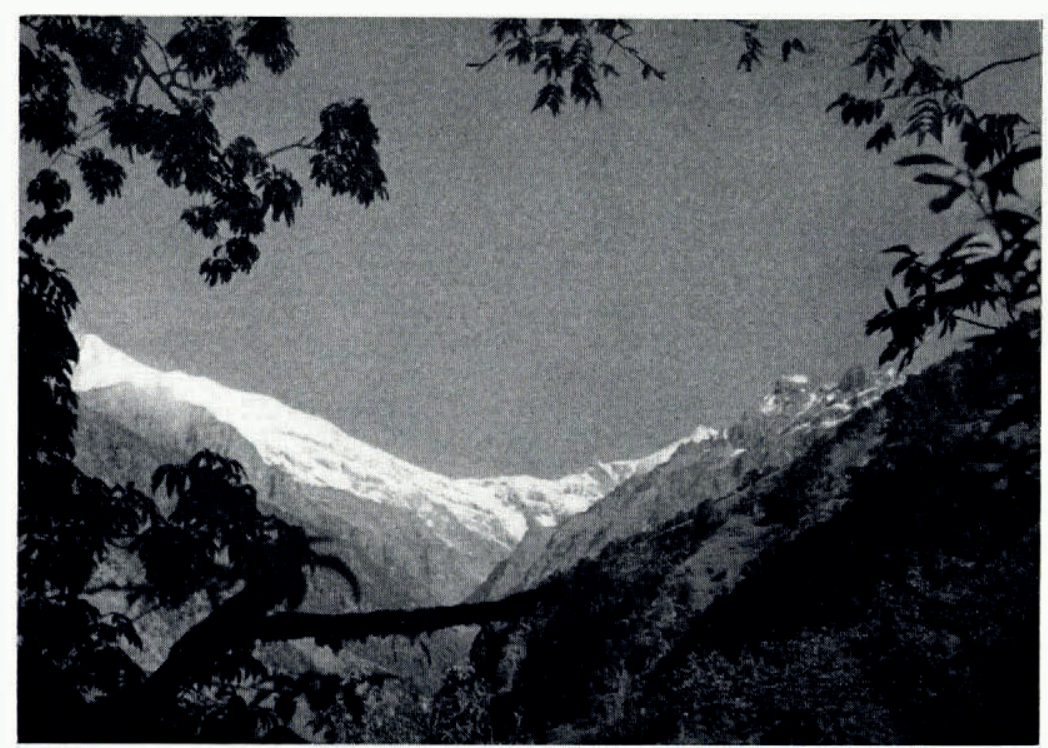

Fig. 3. View of the Pindari Glacier from approximately 3 miles $(4.8 \mathrm{~km}$.) south of Khati village

The glaciated part of the Pindari valley is flanked by steep walls. The western wall rises from the bank of the river in three steps which are at heights of $11,000 \mathrm{ft}$. $(3,353 \mathrm{~m}$.), I6, o0o ft. $(4,877 \mathrm{~m}$.) and $19,000 \mathrm{ft}$. $(5,79 \mathrm{I} \mathrm{m}$.) south of Martoli. The eastern wall rises gradually up to 
I $2,000-13,000 \mathrm{ft}$. $(3,658-3,962 \mathrm{~m}$.) above which there is a steep rise to $16,000 \mathrm{ft}$. $(4,877 \mathrm{~m}$.). North of Martoli the eastern lateral moraine rises steeply from the banks of the Pindar River

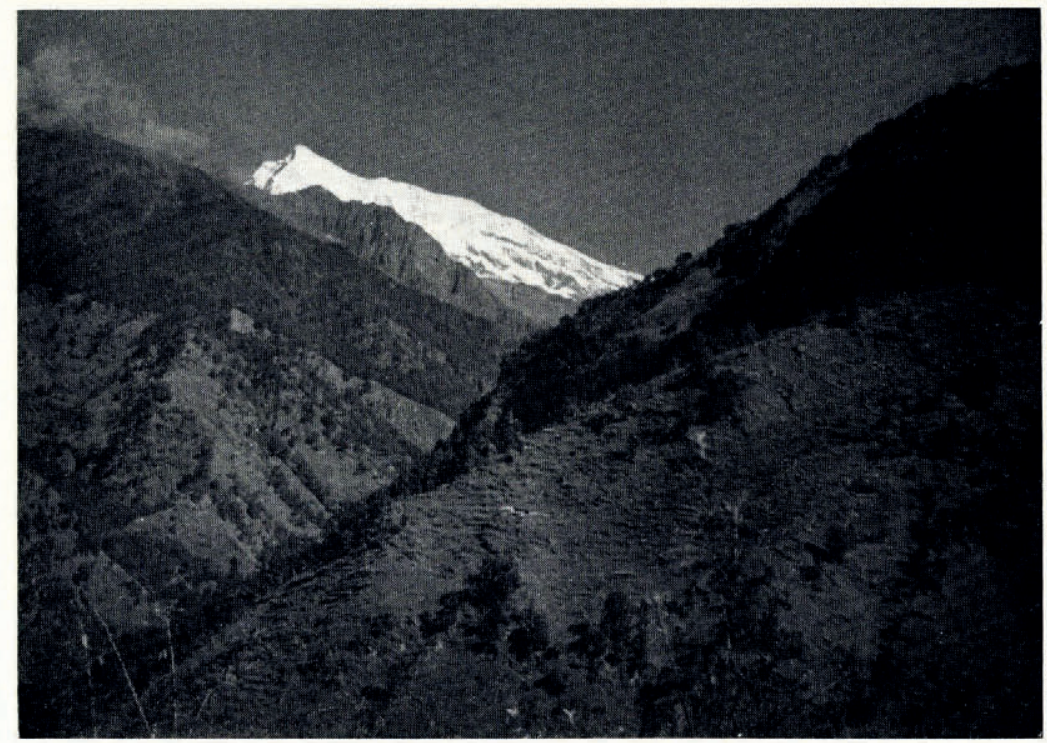

Fig. 4. The Pindari valley viewed from 2 miles $(3 \cdot 2 \mathrm{~km}$.) north of Khati village

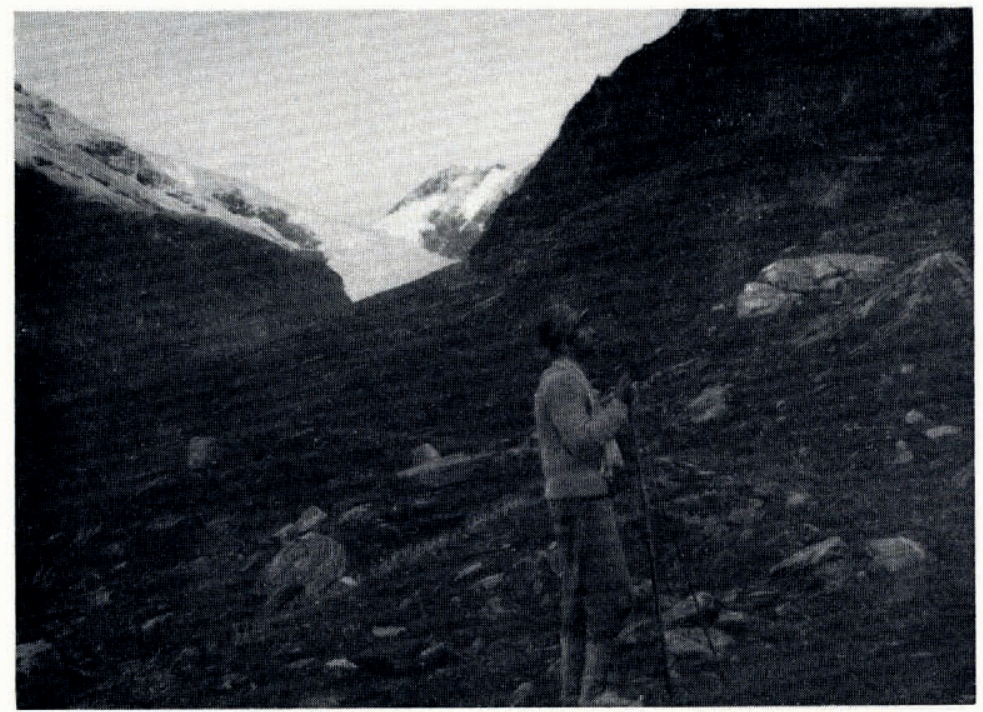

Fig. 5. The lateral moraine along the eastern wall of the Pindar River north-east of Martoli

to a height of $500-\mathrm{I}, 000 \mathrm{ft}$. $\left(\mathrm{I}_{5}^{2-305} \mathrm{~m}\right.$.) and the area between the eastern lateral moraine and the eastern valley wall slopes gently in a south-westerly direction. 


\section{Moraines}

With the exception of some dirty ice near its snout, the Pindari Glacier does not appear to carry much morainic material; most of it has been washed away by the melt-water stream. Consequently, the Pindari Glacier could not deposit any high end moraines; however, between Martoli and its snout several low end moraines of recent origin were recorded. The western lateral moraine is poorly developed and rests on the rocky side of the valley, but the eastern lateral moraine and the medial moraine are well developed. The eastern lateral moraine (Fig. 5) is more than I mile ( $\mathrm{I} .6 \mathrm{~km}$.) long and ends 0.5 miles $(0.8 \mathrm{~km}$.) north of Martoli. The medial moraine is about $660 \mathrm{yd}$. $(605 \mathrm{~m}$.) in length and it has now completely dammed the southward movement of the Pindar Glacier. Near Martoli several crescentshaped, grass-covered end moraines lie across the bed of the Pindar River. They rise gradually from the valley floor above the western lateral moraine. However, there are also moraines at several localities between the gorge of the Pindar River and the newly built Phurkia Dak bungalow. Due to continued erosional activity of the Pindar River and other melt-water streams, morainic types are seldom distinguishable.

The morainic material brought down by the Pindari Glacier is composed mostly of clay and silt, and it contains very few boulders and cobbles; however, some large boulders and cobbles occur in the old moraines.

\section{The Pleistocene Glaciation}

It appears that in the past the Pindari valley was intensely glaciated and it has probably experienced only two glacial advances. During the first advance (which was also probably the period of maximum glaciation) the glacier descended to at least 2 miles $(3 \cdot 2 \mathrm{~km}$.) below the present gorge of the Pindar River. The lateral and subglacial moraines and the rough U-shape of the valley as far as this point provide sufficient evidence of this limit. Terra and Paterson (I939), and Heim and Gansser (I939) have recorded that in most parts of the Himalayas the maximum advance of glaciers was down to about 6 ,ooo ft. ( $1,829 \mathrm{~m}$.), but unfortunately this valley does not show any definite evidence of glacial advances below $9,000 \mathrm{ft}$. $(2,743 \mathrm{~m}$.). It would appear that the constriction of the Pindari valley at the gorge caused most of the ice to be dammed up, and the little that escaped from the gorge melted before it could reach a level of $9,000 \mathrm{ft}$. $(2,743 \mathrm{~m}$.).

During the first phase of the Pindari glaciation a $3,000 \mathrm{ft} .(914 \mathrm{~m}$.) deep valley was cut in gneisses, suggesting a prolonged period of glaciation which possibly included the first three Himalayan glaciations postulated by Terra and Paterson (1939).

After its first advance the Pindari Glacier gradually retreated to some distance above the Pindar River gorge and halted near Martoli. Due north of this point the western valley wall rises from the bed of the Pindar River without a break, but in the south it has a step cut at I $2,000 \mathrm{ft}$. $(3,658 \mathrm{~m}$.). This pattern further implies that in the north the glaciation continued without a break while in the south the advance was preceded by a retreat.

During its second advance the glacier reached the Pindar River gorge, but it appears that it did not advance very far beyond this point. The presence of morainic material below the gorge may represent the remnants of the end moraines of this glaciation. The glacier perhaps occupied the whole of the valley above the gorge, since there is glacial till up to a height of I3, Ooo ft. $(3,962 \mathrm{~m}$.) along the eastern wall.

After this second advance the glacier's retreat was very swift in its initial stages but it slowed down as the recession reached Martoli. No end moraines have been recorded between Martoli and the gorge, but north of Martoli there are traces of several end moraines. During this retreat the Pindari Glacier was probably moving straight towards the Pindar River gorge but later on it was gradually forced towards the western wall by the overloaded and swift-moving Banghatia Glacier. This abrupt change in its direction was further influenced by the medial moraine which dams the Pindari Glacier at its confluence with the Banghatia 
Glacier. Subsequent to this retreat the two lateral moraines, as well as the end moraines between them, were deposited.

\section{Conclusions}

From all the available evidence it appears that during the last hundred years the rate of retreat of the Pindari Glacier has been phenomenal. During r885-94 a retreat of roo yd. (9 $1 \mathrm{~m}$.) was recorded by Mitchell (unpublished). Cotter and Brown (Igo6) recorded the position of the glacier snout about $\mathrm{I}$ mile $(\mathrm{I} \cdot 6 \mathrm{~km}$.) from the end of the medial moraine. When the authors visited this glacier they observed that the snout position was not far above the end of the medial moraine, at a height of $12,500 \mathrm{ft}$. (3,8 $10 \mathrm{~m}$.). The Banghatia Glacier had also retreated farther up-valley. In the light of these observations, the authors are of the opinion that the annual rate of retreat may be about $\mathrm{I}_{32} \mathrm{ft}$. $(40 \cdot 2 \mathrm{~m}$.). The authors also believe that the morainic material recorded north of Khati is of pro-glacial origin, since this part of the valley is V-shaped. During Pleistocene times the Banghatia Glacier was probably more active than at present and carried a large amount of coarse morainic material.

MS. received 15 May 1962

\section{REFERENCES}

Cotter, G. de P., and Brown, J. C. 1906. Notes on certain glaciers in Kamaon. Record of the Geological Survey of India, Vol. 35 , Pt. 4 , p. $148-57$.

Heim, A., and Gansser, A. 1939. Central Himalayas: geological observations of the Swiss expedition, r936. Denkschriften der Schweizerischen Naturforschenden Gesellschaft, Bd. 73, Lief. I.

Mitchell, J. W. A. Unpublished. Notes in the Phurkia Dak bungalow log book.

Strachey, R. 1847. A description of the glaciers of the Pindur and Kuphinee Rivers in the Kumaon Himálaya. Journal of the Asiatic Society of Bengal, Vol. 16, Pt. 2, p. 794-812.

Terra, H. de, and Paterson, T. T. I 939. Studies on the Ice Age in India and associated human cultures. Washington, D.C., Carnegie Institution of Washington. (Carnegie Institution of Washington Publication No. 493.) 